Copyright (C) 2018 by Academic Publishing House Researcher

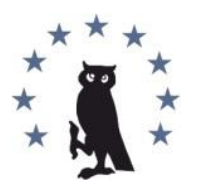

Published in the Russian Federation

European Researcher. Series A

Has been issued since 2010.

ISSN 2219-8229

E-ISSN 2224-0136

2018, 9(1): 9-13

DOI: 10.13187/er.2018.1.9

www.erjournal.ru

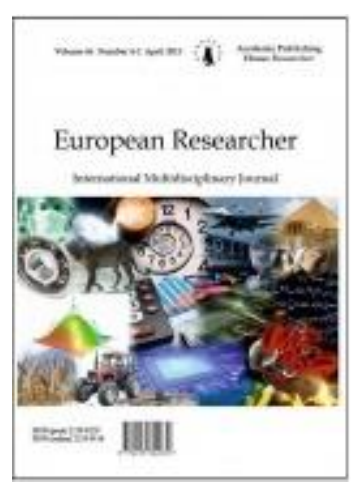

\title{
Human Trafficking: A Sociological Study on Tribal Women of Jharkhand
}

\author{
Sribas Goswami a , *

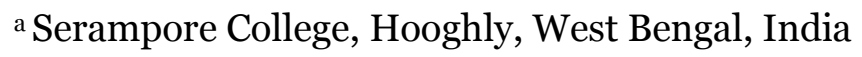

\begin{abstract}
Trafficking of women and girls is a gross violation of human rights of human rights, which needs to be addressed. Trafficking assaults human dignity, flagrantly violates fundamental human rights, erodes consciences, thus fomenting corruption. It is also called modern-day slavery, whereby the victim him/herself "accepts" his/her situation due to the lack of substantial choices and ways out of poverty. Key social determinants that facilitate selling of the women's and girls and their exploitation include poverty, female gender, lack of policy and enforcement, age, migration, displacement and ethnicity, culture, ignorance of trafficking methods, and caste status. Therefore the need of the hour is a serious reflection on the social, ethical, and religious implications of this inhuman issue. The State's responsibilities to these challenges and how to make use of its various resources for combating trafficking is a serious concern of this research. Therefore this paper also investigates the proximate explanatory factors behind modern-day slavery and issue of the region and will serve as a tool in bridging the gap and shaping the future of the women and children of this reign. Since the issue of human trafficking in Jharkhand is a wide phenomenon, the research is exclusively focusing on cause of trafficking of the adivasi (tribal) women and girls of Sahibganj district, Jharkhand. This research is concentrated on two blocks of Sahibganj district of Jharkhand.

Keywords: human trafficking, poverty, patriarchy, migration, tribe.
\end{abstract}

\section{Introduction}

Trafficking of women and minor girls continues to be widespread in Jharkhand and has today emerged as a major source area for inter-State trafficking in India. Most of the trafficking from Jharkhand is from tribal communities for domestic labour to metropolitan cities where there is a demand for such work. In cities like Delhi, a number of illegal placement agencies have cropped up. These agencies take advantage of legal loopholes to traffic mostly innocent women and girls in the name of providing employment, but instead are put into either cheap lalour or extreme conditions of Bonded Labour and forced labour, where 12-14 hours of work every day is a routine practice for these women and girls. Apart from that there is physical and sexual abuse. Several cases of Sexual slavery have also been reported from the victims rescued in Delhi. Some of the victims are trafficked to Haryana and Punjab for the purpose of Forced marriage. Recent news reports also point to the emergence of trafficking of women from Jharkhand for surrogacy, deliver babies who are then sold off (Chistopher, 2008).

Victims of trafficking are identified as being at extremely risk. Therefore in this paper the various effects and consequences faced by the victims of trafficking are discussed. The paper deals

\footnotetext{
${ }^{*}$ Corresponding author

E-mail addresses: sribasgoswami@gmail.com (S. Goswami)
} 
with the consequences of trafficking like physical and sexual exploitation, health, social stigma, social exclusion and other form of most oppressive exploitation, etc. (Mehta, 1982).

\section{Method of research}

This paper is an outcome of empirical research which is explanatory in nature. The research involves both qualitative and quantitative methods. It tries to analyze the problems and at the same time find out the factors leading to the trafficking of women and the girls. Empirical study is based on questionnaires with the government officers, victims of trafficking, and village heads, local community. Various books from different libraries, articles, journals, newspaper cutting have been used as secondary sources for data collection.

Sahibganj district is one of the twenty-four districts of Jharkhand state. Set within the lush green region, the district of Sahibganj with a predominantly tribal population, is one of the six districts comprising Santhal Pargana division. It is considered as one of the backward district of India. Sahibganj have a history of being among the least - developed in the whole country. The vast tract of land enclosed between the hills ranges had been assigned these names; Damin-I-Koh is a Persian word and means 'skirt of the hills". The district may be divided into three natural divisions. One is the hilly portion, consists of the uplands, undulations long ridges and depressions which is inhabited by the tribal. Second portion, this area has plenty of fertile lands and is richly cultivates and majority inhabited by non-tribals (Banerji, 1986). The third region is a narrow strip of low, fertile, alluvial plain lying between the Ganges and the hills running along the loop line of the Eastern Railway inhabited by majority non-tribal constituencies, Census 2011 figures indicated that the percentage share of scheduled caste population to total population was 6.29 per cent while that of Scheduled tribes was 26.80 per cent. The total number of villages in the district is 1,819 . Of these, 1,307 are inhabited and 512 uninhabited. Males constitute $51.33 \%$ of the population and females $48.66 \%$. Among the tribes the Santhals are in the majority.

\section{Discussion}

\section{Effects of trafficking on women and girls \\ Physical effects:}

Women and girls are trafficked into gender-specific situations of exploitation such as exploitative forced labour in domestic servitude, and unorganized sector (Mies, 1986). They face eve-teasing, harassment in the work place, more over they are paid low wages for the same amount of work as agricultural labour, plantation worker, mine worker and construction worker. Being non-locals, they could neither raise their voice nor could establish a strong base to protest against the exploitation meted out to them by their employer. Whether a sex worker or sex slave, or domestic servant, the conditions in which these women live are generally equally horrendous (Dayal, 2001). Many individuals lack adequate sleeping conditions, facilities for bathing, washing clothes, and personal hygiene, and if available, is poorly maintained. Additionally, they are routinely denied or unable to acquire proper nutrition and health care.

\section{Sexual assault and forced surrogacy:}

The effect of trafficking of woman and girls is reflected in sexual molestation, sexual harassment, rape, forced prostitution, torture, domestic abuse, etc. Sexual assault is nonconsensual sexual contact that is obtained through coercion or the use or threat of force. Sexual assault is a deliberate act of gender-based violence and an expression of power, control and domination over another (Iyer, 1986). Upon arrival, these women and girls are used, abused, threatened and sold in the sex industry and are forced to act as a surrogate mother and deliver children by human traffickers. Often, traffickers keep victims under their control by saying that they'll be free after they pay their debt. The "debt" is supposedly incurred from the victims 'recruitment, transportation, upkeep or even their crude "sale". If the victim objects, they are raped, sexually assaulted and abused. It can be observed that tribal women experienced both physical and sexual abuse at work place (Dewan, 2006).

They experience emotionally and physically scarring situations, inhuman treatment, and they are treated like a money minting machine. Very often, all that traffickers want was that they deliver babies as surrogate mother. Well organized groups have been trafficking girls and young women from Jharkhand. According to civil society groups, about 10,000 children are trafficked from Jharkhand from every year to either work as domestic help or sex workers, they are trafficked for 
conceiving children, local residents claimed. Some girls were even forced to conceive babies for sale in Jharkhand. The sexual exploitation of migrant tribal women working at construction site by masons, contractors, the place and others is a routine affair (Mitra, 2013).

\section{Forced marriage:}

Girls and women are not only trafficked for prostitution but also bought and sold like a commodity in many regions of India like Haryana, Punjab where the female ratio is less as compared to male due to female infanticide. Domestic servitude can also be linked to forced marriage. Forced marriage is a marriage without the consent of one or both parties, and a violation of human rights (Jayaswal, 2001). In case of minors, it's also a case of child enslavement. Forced marriage is a mix of several forms of slavery, including forced labour, sexual enslavement and domestic servitude. The root cause is the poverty, unemployment, and underemployment and Sahibganj is one of the tribal community are trafficked and sold in Haryana, Punjab etc. for forced marriage (Ernni, 2012).

\section{The effects of trafficking on labour:}

\section{Domestic servitude:}

The demand for domestic workers has been ever growing with globalization and urbanization, and to match this demand with a continuous supply of domestic workers the middlemen or the placement agencies have come to the fore, which is often intrusive, exploitative and profit-oriented. And tribal women and girls are the most easily available labour force, and the autonomous migration of tribal women domestic workers happens through chain migration. The luckier ones end up as domestic helps (Jayeraj, 2008). The others are sold in marriage or to a brothel where they suffer never-ending abuse in all forms. A large section of domestic workforce, particularly in Delhi, comes from the tribal belt of Jharkhand. There is also a high demand for tribal girls as they are considered to be simple, cheap and industrious and most importantly without a support structure. Hundreds of single tribal women and girls are being trafficked from these poverty-stricken areas. The trafficked victims are kept in congested rooms, fed barely enough for survival till they are placed somewhere (Ferdandes, 1987). These victims of trafficking have to go through series of exploitation starting from the source-traffickers, placement agents to employers.

\section{Forced labour:}

Forced labour can include forced sexual services. Forced labour is the type of enslavement used across the world to produce any products in our global supply chains, while trafficking for forced labour is recently gaining more recognition on its severity; trafficking for sexual exploitation is still the most common form of human trafficking. The primarily impacts women and children (Fuchs, 1992). Victims trafficked for forced labour are often made to work in hidden locations, such as agricultural fields in rural areas, mining camps, factories and private houses in the case of domestic servitude. As a consequence, the trafficking victims of forced labour are less likely to be identified than the trafficking victims of exploitation. Along with women and girls, both adult men and boys are also the victims of trafficking for forced labour but the trafficking cases of men, women and girls are extremely underreported (Kannongo, 2011).

\section{Bonded labor:}

Bonded labour is designed to exploit workers across a variety of industries in order to produce products. The cyclical process begins with a debt, whether acquired or inherited, that cannot be paid immediately. Then, while the worker labors to repay the debt, the employer continues to add on additional expenses (Gupta, 2001).

Tribal Migrant laborers, particularly women and girls, are vulnerable to this form of enslavement. Vulnerability often applies to these tribal populations that are severely deprived socio-economically. Besides being forced to work as domestic laborers or being exploited by the small-scale sector, people are trafficked for agricultural, construction or industrial work. Instead of honoring a genuine term of employment, some recruiters or employers unlawfully exploit the initial debt by adding immigration, housing and other fees that are designed to keep the trafficked victim from ever being capable of repayment (Bhagat, 2011).

\section{Experiences of the victims}

\section{Health implications of trafficking:}

In 2011, 1,095 STI/RTI episodes were treated in the Sahibganj district. Victims of sex trafficking are likely exposed to adverse conditions that can negatively affect their physical, mental 
and emotional health (Kumari, 2001). Physical abuse can result in serious injuries and lasting health problems; trafficking victims may also contract life-threatening diseases, such as HIV/AIDS or tuberculosis. In addition, as a result of trauma, lack of independent income generation prevents the women and girls with HIV/AIDS positive from getting tested, from disclosing their HIV/AIDS status, from accessing services for the prevention and treatment, even though they know they have been infected. Trafficking victims often suffer from serious physical abuse, exhaustion and starvation (Chrristina, 2008). Typical injuries can include broken bones, concussion, bruising or burns, as well as other injuries consistent with assault. Some of these serious injuries can cause lasting health problems and may require long-term treatment. Because women who have been trafficked have been subjected to multiple abuses over an extensive period of time, they may suffer health consequences similar to those of victims of prolonged torture (Resley,1987).

\section{Discrimination:}

Belonging to an indigenous community means they are poor, less educated sections of society, hence the women suffer from all sorts of discrimination, exploitation, marginalization and human rights violations across India. Unemployment is the major reason followed by poverty (Maharaj, 1982). They regret and expressed their difficulties. Physical abuse and feeli8ng of bondage was reported by the women in the three major cities i.e. Delhi, Mumbai, Kolkata. Innocent women were made to working unusually long hours at their working place. Of all categories of exploitation, the exploitation that is predominant is economic exploitation in the form of lower wages than agreed or being paid only $25 \%$.There is physical abuse, torture, beating, rape, mental harassment to them by their supervisors, employers in terms of quality of work, working conditions (George, 2014).

\section{Social boycott:}

While trafficking most directly affects individual victims, it also has consequences for the entire community. Trafficking contributes to the breakdown of societies by removing individuals from their own social networks and family structures. This prevents the transmission of social and cultural values that are usually passed from generation to generation (Banerji, 1986). Trafficked women engaging in sex work tend to have fewer resources, limited options, and increased vulnerability to violence and abuse than women who are not trafficked. Social stigma and nonacceptability are said to the greatest obstacles to reintegration. Besides being stigmatized as outcasts and facing moral and legal isolation, trafficked people are vulnerable to HIV/AIDS infection. It was observed that the migrant girls who returned to their villages found it difficult to get married within the tribal communities, since they were suspected of having become HIV positive, resulting in social boycott of the girl and in certain cases, the entire family is subjected to isolation and social exclusion (Khanna, 1998).

\section{Conclusions}

Trafficking victims of labour and sexual exploitation face threats of violence from many sources, including traffickers, domestic service employers, customers, pimps, brothel owners, and corrupt local law enforcement officials. Victims experience double physical violence form both in the hands of trafficker as well as in the hands of law enforcement during raids. In addition to coping with their past traumatic experiences, former trafficking victims often experience social alienation in the villages. Stigmatization, social exclusion and intolerance often make it difficult for the victims to integrate into their own community. The victims also experience psychological effects that induce threats, fear, and depression, disturbance, extreme stress and emotional violence. Finally, under these pressures, the victims fall into the hopeless metal state of learned helplessness.

\section{References}

Resley, 1987 - Resley A. (1987). We Experience Christ More in Our Struggle than in Biblical Phrases. in To Set At Liberty Those Who Are Oppressed? Singapore: Christian Conference Asia.

Banerji, 1986 - Banerji, S. (1986). Rural Scene. In Agrarian Struggles in India, edited by A.R. Desai, Delhi: Oxford University Press.

Bhagat, 2001 - Bhagat, L.N. (2001). Backwardness and Development of Jharkhand: Some Basic Issues. In Backwardness of Jharkhand: Causes and Remedial Measures edited by L.N. Bhagat and U.K. Verma, Chakradharpur: Jawahar Lal Nehru College. 
Chrristina, 2008 - Chrristina, D. (2008). Struggle Against Land Alienation-A Study of Mahasweta Devi's Short Story 'Little Ones.' In Human Rights and Higher Education, edited by Lily Balasingh, Briget Mary, and Jesudasan Jeyaraj. Madurai: Lady Doak College Publication.

Christopher, 2008 - Christopher, K. (2008). Christian Perspective of Children's Right. In Human Rights and Higher Education, edited by Lily Balasingh, Briget Mary, and Jesudasan Jeyaraj. Madurai: Lady Doak College Publication.

Dayal, 2001 - Dayal, H. (2001). Jharkhand: An Abode of the Poor and Deprived. In Backwardness of Jharkhand: Causes and Remedial Measures edited by L.N. Bhagat and U.K.Verma, ${ }^{\text {st }}$ ed. Chakradharpur: Jawahar Lal Nehru College.

Dewan, 2006 - Dewan, R. (2006). The Socio-Economic Status of Tribal Women in Jharkhand. In Inside Jharkhand,edited by Sunil Kumar Singh, $6^{\text {Th }}$ ed., Ranchi:Crown Publications.

Erni, Shimreichon, 2012 - Erni, Shimreichon L. (2012). Violence, Customary Law and Indigenous Women's Rights In Asia. In End Violence against Women, Thailand: Asia Indigenous Peoples Pact.

Fernandes, Geeta, 1987 - Fernandes, W., Geeta M. (1987). Tribal Women and Forest: Background and Methodology. In Tribal Women and Forest Economy: Deforestation, Exploitation and Status Change, edited by Walter Fernanades, Delhi: Indian Social Institute.

Fuchs, 1992 - Fuchs, S. (1992). Messianic Movement among the Tribals of North-Eastern Central India., In Godmen on the Warpath: A Study of Messianic Movement in India, New Delhi: Munshiram Manoharlal Publishers Pvt Ltd.

George, 2014 - George, A. (2014). S. Status Of Adivasis/Indigenous Peoples Mining: Jharkhand: An Adivasi Home Land. First. Series-2. Delhi: Aakar Books.

Gupta, 2001 - Gupta, S. (2001). Backwardness of Jharkhand: A Study in Historical Perspective. In Backwardness of Jharkhand: Causes and Remedial Measures edited by L.N. Bhagat and U.K. Verma, $1^{\text {st }}$ ed. Chakradharpur: Jawahar Lal Nehru College.

Gopal, Maharaj, 1986 - Gopal I.K., Maharaj R.N. (1986). Agrarian Movement in Tribal Bihar (Dhanbad), 1972-80. Edited by A.R. Desai, Delhi: Oxford University Press.

Jayaswal, Bhagat, 2001 - Jayaswal, M., Bhagat R.N. (2001). A Study of Attitude about

Health Promotion among the Rural Tribal Women of Jharkhand. In Backwardness of Jharkhand: Causes and Remedial Measures edited by L.N. Bhagat and U.K. Verma, ${ }^{\text {st }}$ ed. Chakradharpur: Jawahar Lal Nehru College.

Jeyaraj, 2008 - Jeyaraj, J.B. (2008). Biblical Theology Of Creation:A Basis for Human Rights. In Human Rights and Higher Education, edited by Lily Balasingh, Briget Mary, and Jesudason Jeyaraj. Madurai: Lady Doak College Publication.

Publications.

Kannongo, 2011 - Kannongo, S. (2011). Tribal and Human Rights. Delhi: Swastik

Khanna, 1998 - Khanna, S.K. (1998). Women and the Human Rights. $1^{\text {st }}$ Ed. New

Delhi: Common Wealth Publisher.

Kumari, 2001 - Kumari, K. (2001). Some Lessons from the History of Jharkhand Movement.

In Backwardness of Jharkhand: Causes and Remedial Measures edited by L.N. Bhagat and

U.K. Verma, Chakradharpur: Jawahar Lal Nehru College.

Maharaj, Iyer, 1982 - Maharaj, R.N., Iyer K.G. (1982). Agrarian Movement in Dhandbad.

In Fourth World Dynamics: Jharkhand, Delhi: Authors Guild Publications.

Mies, 1986 - Mies, M. (1986). Patriarchy and Accumulation on a World Scale. London: Zed Books Ltd, 1986.

Mehta, 1982 - Mehta, B.K. (1982). Historical and Cultural Basis of Jharkhandi Nationality. In Fourth World Dynamics: Jharkhand, edited by Nirmal Sengupta, Delhi: Authors Guild Publications.

Mitra, Mishra, 2013 - Mitra M, Mishra S.K. (2013). Child Migration, Child Trafficking and Child Labour in India, New Delhi: ILO Publication. 